\title{
BRACHIARIA IN SELENIUM-CONTAMINATED SOIL UNDER SULPHUR SOURCE APPLICATIONS
}

\author{
Letícia de Abreu Faria ${ }^{(1)}$, Pedro Henrique de Cerqueira Luz ${ }^{(2)}$, Felipe Barros Macedo ${ }^{(2)}$, Paulo \\ Sergio Tonetti ${ }^{(2)}$, Marcos Roberto Ferraz ${ }^{(2)}$, Jairo Antônio Mazza ${ }^{(3)}$ and Godofredo Cesar Vitti ${ }^{(3) *}$ \\ (1) Universidade de São Paulo, Centro de Energia Nuclear na Agricultura, Programa de Pós-graduação em Ciências, Piracicaba, São \\ Paulo, Brasil. \\ (2) Universidade de São Paulo, Faculdade de Zootecnia e Engenharia de Alimentos, Departamento de Zootecnia, Pirassununga, São \\ Paulo, Brasil. \\ (3) Universidade de São Paulo, Escola Superior de Agricultura Luiz de Queiroz, Departamento de Ciências do Solo, Piracicaba, São \\ Paulo, Brasil. \\ * Corresponding author. \\ E-mail: gcvitti@usp.br
}

\begin{abstract}
High contents of plant-available selenium in the soil in the form of selenate, resulting from natural or anthropogenic action, jeopardizes agricultural areas and requires research for solutions to establish or re-establish agricultural or livestock operation, avoiding the risk of poisoning of plants, animals and humans. The purpose was to evaluate sulfur sources in the form of sulfate, e.g., ammonium sulfate, calcium sulfate, ferric sulfate, in the remediation of tropical soils anthropogenically contaminated with Se under the tropical forage grass Brachiaria brizantha (Hochst. ex A. Rich.) Stapf cv. Marandu. More clayey soils are less able to supply plants with Se, which influences the effects of $S$ sources, but it was found that high soil Se concentrations negatively affected forage biomass production, regardless of the soil. Of the tested S sources, the highly soluble ammonium sulfate and ferric sulfate reduced plant Se uptake and raised the available sulfur content in the soil.
\end{abstract}

Keywords: contamination, selenate, remediation, toxicity.

\section{RESUMO: BRACHIARIA CULTIVADA EM SOLOS CONTAMINADOS COM SELÊNIO SUBMETIDA ÀS FONTES DE ENXOFRE}

A existência de elevado teor de selênio disponível nos solos na forma de selenato, originado de forma natural ou por ação antropogênica, condena áreas agrícolas e exige a procura de soluções para estabelecer 


\begin{abstract}
ou restabelecer a exploração agrícola ou agropecuária, evitando riscos de intoxicação das plantas, dos animais e dos seres humanos. Avaliaram-se fontes de enxofre na forma de sulfato, como o sulfato de amônio, sulfato de cálcio, sulfato férrico, na remediação de solos tropicais contaminados antropogenicamente com Se, cultivados com a graminea forrageira de clima tropical Brachiaria brizantha (Hochst. ex A. Rich.) Stapf cv. Marandu. Os solos mais argilosos apresentaram menor capacidade em disponibilizar Se às plantas. Tal fato influenciou nos efeitos das fontes de S, porém verificou-se que os elevados teores de Se dos solos influenciaram negativamente a produção de biomassa da planta forrageira, independentemente do solo. Entre as fontes de S avaliadas, as elevadas solubilidades do sulfato de amônio e do sulfato férrico proporcionaram redução na absorção desse elemento pelas plantas, bem como aumentaram os teores de $S$ disponível no solo.
\end{abstract}

Palavras-chave: contaminação, selenato, remediação, toxidez.

\section{INTRODUCTION}

Selenium (Se) is an essential micronutrient for human and animal nutrition (Terry et al., 2000), but also one of the few elements that can be absorbed by plants in sufficient quantities to cause poisoning of domestic animals (Dhillon and Dhillon, 2003).

Selenium concentration in the soil ranges from 0.005 to $1,200 \mathrm{mg} \mathrm{kg}^{-1}$, and concentrations are naturally high in many parts of the world (Casteel and Blodgett, 2004). The element can be present in the soil due to weathering of rocks and volcanic activity (Combs Jr. and Combs, 1986) or as a result from mineral supplements used for livestock, coal and oil combustion, copper and nickel metallurgy, sewage sludge (1.1-8.7 $\left.\mathrm{mg} \mathrm{kg}^{-1}\right)$, acidity correction, and in phosphate fertilizers (Malavolta, 2006). The soil constituents and human activities define the transfer rates of the element between the different compartments of the ecosystem (Mouta et al., 2008).

High Se levels in soils and pastures may cause chronic and acute poisoning in cattle and horses (Rogers et al., 1990). Some grasses and seeds can accumulate between 1 and $25 \mathrm{mg} \mathrm{kg}^{-1}$ of soluble Se, when grown in Se-rich soils (Casteel and Blodgett, 2004). Areas with more than $5 \mathrm{mg} \mathrm{kg}^{-1}$ Se pose a risk for animals that consume the local vegetation, and areas adjacent to Se-rich regions may also be affected by the transport of surface Se by water or wind (Zhao et al., 2005).

Selenium concentration in forages varies from soil to soil and even within the same soil type, since the plant uptake is influenced by several factors (Lewis, 2000). Selenium uptake by plants is influenced by the chemical form, soil concentration, the soil redox conditions, $\mathrm{pH}$ of the rhizosphere, and the presence of competing anions such as sulfate and phosphate (White et al., 2007).

Chemical properties of Se are very similar to those of sulfur (S), so that Se competes for the sulfate transporters of the root plasma membrane, and once absorbed it is embedded in Se-containing amino acids analog to those containing S (Malavolta, 1980).
Forage plants are considered passive accumulating plants and can contain $10-30 \mathrm{mg} \mathrm{kg}^{-1}$ Se in the dry matter. There are plants classified as primary and secondary accumulators, i.e., capable of retaining hundreds and thousands of $\mathrm{mg} \mathrm{kg}^{-1}$ Se in the dry matter, respectively (Oliveira et al., 2007).

The Se distribution in the soil profile can be influenced by the parent material, organic matter, $\mathrm{pH}$, ferruginous material, and rainfall (Adriano, 1986). The persistence and mobility in the soil are related to phenomena of sorption, desorption, precipitation, complexation, oxireduction, and dissolution (Sparks, 1999). In the soil or in sediments, Se depends on the $\mathrm{pH}$, competition with anions, iron oxides and the type of clay mineral (Dhillon and Dhillon, 2003).

Selenium can be toxic to plants, including in pastures, even at low concentrations, however, the toxicity depends on the plant species, form of Se, and the presence of competing ions such as sulfate and phosphate (Adriano, 1986). The use of S-containing materials such as ammonium sulfate or gypsum is recommended to reduce Se levels in pastures (Rogers et al., 1990). The chemical similarity between Se and $\mathrm{S}$ result in antagonistic interactions of these elements in the soil (Adriano, 1986), and in plant nutrition (Adriano, 1986; Malavolta, 1980). The formation of a selenite-ferric oxide complex tends to protect animals and plants from excess Se (Allaway, 1968).

Selenium levels that meet the nutritional requirements of animals, i.e., from 0.1 to $0.3 \mathrm{mg} \mathrm{kg}-1$ in the dry matter required by cattle (NRC, 2005), are desirable, as long as the forage plant is not affected, since high Se concentrations in the shoots of forage plants can affect their nutritional quality. Secondary or passive accumulators are classified as forage crops by Oliveira et al. (2007), and can develop properly in Se-rich and Se-poor soils without negative consequences, but can accumulate over $1,000 \mathrm{mg} \mathrm{kg}^{-1}$ in the tissue dry matter and can intoxicate grazing animals (White et al., 2007). The existence of high Se content available in the soil, resulting from natural or anthropogenic influence, 
stimulates the search for solutions for agricultural areas in order to understand the performance of forage crops and prevent livestock poisoning. The objective was to evaluate the effects of the application of sulfur sources to tropical soils with high Se levels available in the soil on the cultivation of the tropical forage Brachiaria brizantha (Hochst. Ex A. Rich.) Stapf cv. Marandu.

\section{MATERIAL AND METHODS}

This greenhouse experiment was conducted under controlled humidity and temperature conditions, using samples from three tropical soils. The soils, classified as Nitossolo Vermelho Eutroférrico (Typic Hapludoll), Argissolo Amarelo Distrófico abrúptico (Arenic Hapludult) and Latossolo Vermelho Distroférrico (Rhodic Hapludox), were artificially contaminated with high Se amounts, by the application of sodium selenate 30 days before the start of the experiment. The samples of each soil were homogenized under plastic canvas with a hoe and later one composite sample per soil type was prepared for physical (Table 1) and chemical analysis (Table 2), prior to the pot experiment.

Acidity was only corrected in the Argissolo Amarelo Distrófico abrúptico (Arenic Hapludult) to reach a base saturation of $60 \%$, as recommended for forage grass cultivation (Raij et al., 1997) with a

Table 1. Granulometry of the three studied soils

\begin{tabular}{lccc}
\hline Soil & Total sand & Clay & Silt \\
\hline & \multicolumn{3}{c}{$\mathrm{mg} \mathrm{m}^{-3}$} \\
\cline { 2 - 4 } $\begin{array}{l}\text { Nitossolo Vermelho } \\
\begin{array}{l}\text { Eutroférrico } \\
\text { Argissolo Amarelo }\end{array}\end{array}$ & 323 & 449 & 227 \\
$\begin{array}{l}\text { Distrófico abrúptico } \\
\text { Latossolo Vermelho }\end{array}$ & 849 & 85 & 66 \\
Distroférrico & 305 & 554 & 141 \\
\hline Pipette method (Emapa, & & & \\
\hline
\end{tabular}

Pipette method (Embrapa, 2011). lime application rate $(\mathrm{PRNT}=100 \%)$ of $1.45 \mathrm{Mg} \mathrm{ha}^{-1}$, and incubation for 30 days.

The experiment was arranged in a completely randomized, factorial design $(3 \times 4 \times 2)$ with four replications. Three tropical soils with different physical (Table 1) and chemical properties (Table 2) were tested, with significant representation in the State of São Paulo and occurrence across Brazil and four treatments (ammonium sulfate, calcium sulfate, ferric sulfate at a dose of $600 \mathrm{~kg} \mathrm{ha}^{-1}$ sulfur and a control treatment without sulfur) were applied and evaluated in two forage cuts. The $\mathrm{S}$ sources were also evaluated for their solubility. The solubility of ferric sulfate and ammonium sulfate were high (440 and $706 \mathrm{~g} \mathrm{~L}^{-1}$, respectively), while calcium sulfate was less soluble $\left(2.44 \mathrm{~g} \mathrm{~L}^{-1}\right)$, but is nevertheless a soil conditioner that is increasingly used in agriculture and widely available in Brazil.

The forage Brachiaria brizantha (Hochst. Ex A. Rich.) Stapf cv. Marandu was studied, in view of its high yield potential and importance in the agricultural scenario of Brazil and the tropics. The grass was germinated in vermiculite and planted in experimental units consisting of pots with $7 \mathrm{dm}^{-3}$ of air-dried soil. The shoots were uniformly cut at $0.15 \mathrm{~m}$ above the soil, 30 days after seedling transplanting.

Sulfur treatments, except for the little soluble calcium sulfate, were diluted in deionized water and applied as fertilizer solution to the plantation (Raij et al., 1997). In order to isolate the effects of $\mathrm{N}$ contained in ammonium sulfate, ammonium nitrate $\left(500 \mathrm{~kg} \mathrm{ha}^{-1} \mathrm{~N}\right)$ was applied to the other treatments.

Thirty and sixty days after the first levelling cut, two cuts were made, the first $0.05 \mathrm{~m}$ above the soil and the second at ground level. The plants were assessed for: dry matter production - SDM, bromatological-chemical properties of the aerial part and at the end of the second cut, root dry matter production - RDM, assessed after removal of the root system from the pots and washing under running water in a sieve. All sampled plant material was oven-dried at $65^{\circ} \mathrm{C}$ for $72 \mathrm{~h}$, to determine dry matter production.

Table 2. Chemical characterization of the three studied soils

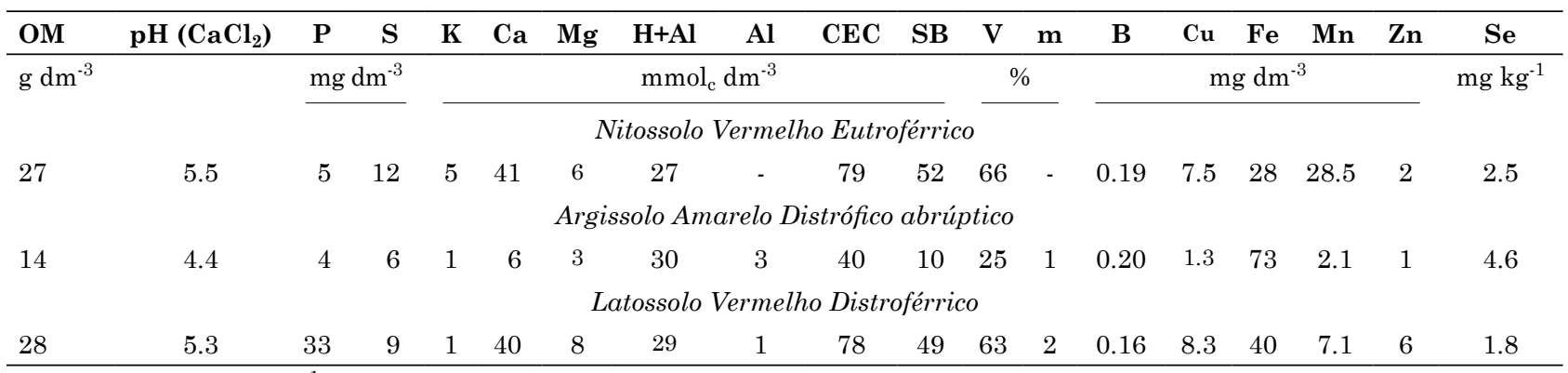

pH in $\mathrm{CaCl}_{2} 0.01 \mathrm{~mol} \mathrm{~L}^{-1}$; P, K, Ca and Mg: extracted by Resin method; S: extracted by Calcium phosphate; Al: extracted by 1 mol L ${ }^{-1} \mathrm{KCl}$; H+Al: Buffer SMP; OM: organic matter, Walkley-Blake method; B: hot water; Cu, Fe, Mn and Zn: extracted by DTPA. 
Soil fertility and residual Se levels in the soil were evaluated. The total Se contents in the soil and plants were determined by digestion on a heating plate with $\mathrm{HNO}_{3}$ and $\mathrm{H}_{2} \mathrm{O}_{2}$ and recovered in $10 \mathrm{~mol} \mathrm{~L}^{-1} \mathrm{HCl}$, with determination by hydride generation in ICP-AES. Crude protein was quantified by the micro-Kjeldahl method (AOAC, 1980). The leaf samples were analyzed according to Embrapa (1979), namely $\mathrm{P}$ by colorimetry of molybdate-vanadate, $\mathrm{S}$ by turbidimetry, $\mathrm{K}$ by emission spectrophotometry, and $\mathrm{Ca}, \mathrm{Mg}, \mathrm{Fe}, \mathrm{Mn}$, and $\mathrm{Zn}$ concentrations by atomic absorption spectrophotometry.

To verify the translocation of Se from soil to biomass, and thereby predict the potential toxicity of the forage when used as animal feed as well as the effects of the sulfate treatments, the bioconcentration factor was calculated by the modified method of Yoon et al. (2006), defining the effect of the biomass Se concentration from the soil content. The chemical properties of soil fertility were analyzed as described by Raij et al (2001), and P, K, Ca, and Mg by ion exchange resin, $\mathrm{S}$ by calcium phosphate, $\mathrm{B}$ by hot water extraction and the micronutrients $\mathrm{Zn}, \mathrm{Cu}, \mathrm{Fe}$, and Mn by DTPA. Potassium was determined by emission spectrophotometry, $\mathrm{Ca}, \mathrm{Mg}, \mathrm{Cu}, \mathrm{Fe}, \mathrm{Mn}$, and $\mathrm{Zn}$ by atomic absorption spectrophotometry, and $\mathrm{B}$ and $\mathrm{P}$ by colorimetry and $\mathrm{S}$ by turbidimetry.

Data were analyzed using PROC MIXED of software SAS (2004) and analysis of variance, and the means compared by the Tukey test $(p<0.01)$.

\section{RESULTS AND DISCUSSION}

The high Se levels available in the soil had phytotoxic effects on the early development of the grass, which showed the symptoms cited by Malavolta (1980), e.g., stunted growth and chlorotic leaves. The favorable effects of the treatments with ammonium sulfate and ferric sulfate were expressed in increased plant development. In the treatments control (no S) and calcium sulfate, i.e., in the absence and low solubility of S, respectively, toxicity incidence was higher, causing damage to the plant development and inducing plant senescence. In the mean, the SDM in these two treatments was respectively, only 25.9 and $29.5 \%$ of that in the treatments with ammonium sulfate and ferric sulfate.

The SDM was affected the interactions treatments - cuts and treatments - soils (Table 3). In the first cut, only SDM was evaluated, due to the phytotoxic effects resulting in insufficient plant production to perform analyses. Differences between treatments were observed at both cuts, and SDM and RDM were highest in the treatments with application of ferric sulfate and ammonium sulfate in all soils (Table 3 ).

The mean dry matter production in the second cut was higher than in the first, but the high Se availability in the soils, absence of sulfate in the control treatment and the lower efficiency of the treatment with calcium sulfate in soil reduced SDM in both cuts, and RDM in these two treatments (Table 3). The lower efficiency in reducing the phytotoxic effect of the calcium sulfate treatment was confirmed by the absence of difference from the control treatment, while the other treatments produced higher RDM and SDM.

The effect of the interaction treatments-soils on SDM (Table 3) was observed in that SDM was lowest on the Argissolo Amarelo Distrófico abrúptico (Arenic Hapludult), even under application of the

Table 3. Dry matter production of shoots (SDM) and roots (RDM) of Brachiaria brizantha cv. Marandu in soils with high selenium content subjected to remediation treatments in the three studied soils

\begin{tabular}{|c|c|c|c|c|c|}
\hline Soil & Control & Ammonium sulfate & Calcium sulfate & Ferric sulfate & Mean \\
\hline & \multicolumn{5}{|c|}{ SDM (g per pot) } \\
\hline Argissolo Amarelo Distrófico abrúptico & 6.6 Ba & $14.2 \mathrm{Ab}$ & $3.6 \mathrm{Ba}$ & $11.1 \mathrm{Ab}$ & $8.87 \mathrm{~b}$ \\
\hline Latossolo Vermelho Distroférrico & $6.7 \mathrm{Ba}$ & $18.6 \mathrm{Aa}$ & $5.6 \mathrm{Ba}$ & $19.2 \mathrm{Aa}$ & $12.49 \mathrm{a}$ \\
\hline Nitossolo Vermelho Eutroférrico & $1.5 \mathrm{Bb}$ & $20.8 \mathrm{Aa}$ & $3.8 \mathrm{Ba}$ & 16.9 Aa & $10.76 \mathrm{a}$ \\
\hline $1^{\text {st }}$ cut & $2.0 \mathrm{Bb}$ & $11.0 \mathrm{Ab}$ & $1.6 \mathrm{Bb}$ & $10.3 \mathrm{Ab}$ & $6.23 \mathrm{~b}$ \\
\hline $2^{\text {nd }}$ cut & 7.8 Ba & $24.7 \mathrm{Aa}$ & $7.0 \mathrm{Ba}$ & $21.2 \mathrm{Aa}$ & $15.19 \mathrm{a}$ \\
\hline \multirow[t]{2}{*}{ Mean } & $4.92 \mathrm{~A}$ & $17.85 \mathrm{~A}$ & $4.33 \mathrm{~B}$ & $15.73 \mathrm{~A}$ & \\
\hline & \multicolumn{5}{|c|}{ RDM (g per pot) } \\
\hline Argissolo Amarelo Distrófico abrúptico & $9.0 \mathrm{Ca}$ & $26.8 \mathrm{Aa}$ & $3.8 \mathrm{Ca}$ & $20.5 \mathrm{Bab}$ & $15.01 \mathrm{a}$ \\
\hline Latossolo Vermelho Distroférrico & 7.8 Ba & $20.7 \mathrm{Ab}$ & $7.0 \mathrm{Ba}$ & $23.3 \mathrm{Aa}$ & $14.70 \mathrm{a}$ \\
\hline Nitossolo Vermelho Eutroférrico & $2.3 \mathrm{Cb}$ & $25.8 \mathrm{Aab}$ & 6.6 Ca & $16.4 \mathrm{Bb}$ & $12.74 \mathrm{a}$ \\
\hline Mean & $6.35 \mathrm{C}$ & $24.43 \mathrm{~A}$ & $5.76 \mathrm{C}$ & $20.04 \mathrm{~B}$ & \\
\hline
\end{tabular}

Means followed by the same uppercase and lowercase letters, respectively, in rows and columns do not differ by the Tukey test (p<0.01). 
most soluble sources (ammonium sulfate and ferric sulfate), while the Nitossolo Vermelho Eutroférrico (Typic Hapludoll) had lowest SDM in the control treatment. The influence of Argissolo Amarelo Distrófico abrúptico (Arenic Hapludult) on forage SDM, even in the treatments with ammonium sulfate and ferric sulfate, was possibly related with the higher initial Se soil content. In addition, soil physical and chemical properties may have reduced Se absorption, as a result of the lower clay content than of the other soils, the properties silicate clay and $\mathrm{Al}$ oxide contents influence Se adsorption most (Abreu et al., 2011).

Symptoms of Se phytotoxicity in Brachiaria brizantha cv. Marandu were more pronounced in the initial development of the control and calcium sulfate treatment, but there was a higher efficiency of the sources ammonium sulfate and ferric sulfate in reducing plant Se uptake, although the grass was able to produce biomass even in soils with high Se availability (Table 3). This forage production capacity, even in the control treatment, was possibly favored by high $\mathrm{N}$ availability. The supply of one nutrient can affect the uptake of others and result in toxicity or alteration of responses (Cantarella, 2007). Non-specific interactions, generally those in which nitrogen is involved, can have an effect when one nutrient reaches a concentration near the limits of deficiency or excess. Selenium increased N metabolism in the plant by the activation of nitrate reductase, glutamine synthetase and glutamate synthase, and reduced the highest concentration of total N (Rios et al., 2010).

High $\mathrm{N}$ and $\mathrm{S}$ doses of increased the $\mathrm{CP}$ contents to levels considered high (Table 4), according to the range 8 to $12.5 \%$ (Raij et al., 1997), while values lower than $7 \%$ are limiting for livestock production (Costa et al., 2005). For the CP contents, the factor dilution/concentration must be considered, because the highest $\mathrm{CP}$ levels in the control and calcium sulfate treatments (Table 4) coincided with the lowest SDM (Table 3), as also observed for Se concentration in the second cut (Table 4).

Selenium concentrations of grass dry matter in the second cut were atypical for the classification as passive accumulator plant, because the Se quantities absorbed were similar to those of secondary accumulator plants (Oliveira et al., 2007).

Brachiaria has phytoremediation potential. Yoon et al. (2006) state hyperaccumulator plants can transfer the element from the soil to the root and from the root to the shoot biomass. In addition, the bioconcentration factor of plants suited for phytoextraction must be higher than 1 . However, one should bear in mind that biomass extraction for export of the local Se would be more effective in treatments with ferric sulfate and ammonium sulfate, which were also more effective in interrupting Se uptake by plants and increasing shoot production, which could be harvested and removed from the contaminated environment at the end of each crop growth cycle.

Table 4. Content of crude protein (CP), Se concentration and total Se exported in shoots, and bioconcentration factor of Brachiaria brizantha cv. Marandu in the three studied soils with high Se levels in sulfur source treatments in the second cut

\begin{tabular}{|c|c|c|c|c|}
\hline Soil & Control & Ammonium sulfate & Calcium sulfate & Ferric sulfate \\
\hline & \multicolumn{4}{|c|}{ Crude protein $(\%)$} \\
\hline Argissolo Amarelo Distrófico abrúptico & $14.4 \mathrm{Aa}$ & $10.5 \mathrm{Bb}$ & $14.1 \mathrm{Ab}$ & $13.6 \mathrm{Aa}$ \\
\hline Latossolo Vermelho Distroférrico & $15.9 \mathrm{Aa}$ & $13.2 \mathrm{Ba}$ & $15.9 \mathrm{Aab}$ & $12.5 \mathrm{Ba}$ \\
\hline \multirow[t]{2}{*}{ Nitossolo Vermelho Eutroférrico } & $16.8 \mathrm{Aa}$ & $10.5 \mathrm{Cb}$ & $17.6 \mathrm{Aa}$ & $13.6 \mathrm{Ba}$ \\
\hline & \multicolumn{4}{|c|}{ Se in shoots $\left(\mathrm{mg} \mathrm{kg}^{-1}\right)$} \\
\hline Argissolo Amarelo Distrófico abrúptico & $450 \mathrm{Aa}$ & $132 \mathrm{Ba}$ & $487 \mathrm{Aa}$ & $82 \mathrm{Ba}$ \\
\hline Latossolo Vermelho Distroférrico & $275 \mathrm{Bb}$ & $141 \mathrm{Ca}$ & $404 \mathrm{Aa}$ & $148 \mathrm{Ca}$ \\
\hline \multirow[t]{2}{*}{ Nitossolo Vermelho Eutroférrico } & $115 \mathrm{ABb}$ & $108 \mathrm{Ba}$ & $271 \mathrm{Ab}$ & $56 \mathrm{Ba}$ \\
\hline & \multicolumn{4}{|c|}{ Se exported in shoots $(\mathrm{mg})$} \\
\hline Argissolo Amarelo Distrófico abrúptico & $5.6 \mathrm{Aa}$ & $2.3 \mathrm{Ba}$ & $2.5 \mathrm{Ba}$ & $1.2 \mathrm{Bb}$ \\
\hline Latossolo Vermelho Distroférrico & $2.7 \mathrm{Ab}$ & $3.9 \mathrm{Aa}$ & 4.0 Aa & $4.5 \mathrm{Aa}$ \\
\hline \multirow[t]{2}{*}{ Nitossolo Vermelho Eutroférrico } & $0.6 \mathrm{Ab}$ & $3.2 \mathrm{Aa}$ & $4.2 \mathrm{Aa}$ & $1.2 \mathrm{Ab}$ \\
\hline & \multicolumn{4}{|c|}{ Bioconcentration factor } \\
\hline Argissolo Amarelo Distrófico abrúptico & $116.6 \mathrm{Aa}$ & $28.7 \mathrm{Ba}$ & $79.2 \mathrm{ABb}$ & $17.8 \mathrm{Ba}$ \\
\hline Latossolo Vermelho Distroférrico & $152.8 \mathrm{Ba}$ & $78.5 \mathrm{Ca}$ & $224.3 \mathrm{Aa}$ & $82.1 \mathrm{Ca}$ \\
\hline Nitossolo Vermelho Eutroférrico & $46.1 \mathrm{Aa}$ & $43.0 \mathrm{Aa}$ & $108.3 \mathrm{Ab}$ & $22.4 \mathrm{Aa}$ \\
\hline
\end{tabular}

Means followed by the same uppercase and lowercase letters, respectively, in rows and columns, do not differ by the Tukey test ( $\mathrm{p}<0.01)$. 
Nevertheless, although the shoot Se levels were high in the treatments control and calcium sulfate (Table 4), they were compromised due to the low SDM production.

Thus, the application of ferric sulfate or ammonium sulfate proved efficient in reducing Se concentrations in the shoot dry matter, possibly as a result of competition between Se and S. This contrasted with the calcium sulfate treatment, which did not differ from the control, i.e., although the exported Se quantities were similar or even higher in these treatments, as indicated by the highest bioconcentration factor (Table 4), the application of ammonium sulfate and ferric sulfate caused a dilution effect. In contrast, Rogers et al. (1990) reported that in an experiment with calcium sulfate application $\left(29.65 \mathrm{t} \mathrm{ha}^{-1}\right)$, selenium in the forage dry matter could be reduced from 18 to $2 \mathrm{mg} \mathrm{kg}^{-1}$, which would be rather drastic reduction. The same authors observed that with the application of ammonium sulfate at a rate similar to that used in this experiment, Se contents were reduced from 10 to $1.4 \mathrm{mg} \mathrm{kg}^{-1}$.

The lower solubility of calcium sulfate than of the other treatments reduced the antagonistic relation $\mathrm{SO}_{4}^{2-} / \mathrm{SeO}_{4}^{2-}$ mentioned by Rogers et al. (1990). Dissolution in other treatments was very effective, with high capacity of $\mathrm{SO}_{4}^{2-}$ supply in the soil, in the short term (Table 5). Moreover, the high level of available $\mathrm{N}$ favored plant resistance and allowed forage production at high Se soil contents. Ammonium acts by dilution with increasing plant growth (Rogers et al., 1990).

Forage dry matter from soils with high Se contents is unsuitable for animal consumption, according to the maximum tolerable level for ruminants of $5 \mathrm{mg} \mathrm{kg}^{-1}$ (NRC, 2005). Although the initial Se levels in the evaluated soils were lower than those determined by Zhao et al. (2005) as potentially threatening to wildlife and livestock, the Se concentrations in the forage posed a risk for animals that feed on it.
High potential for biomass production and its bioconcentration factors as well as Se export to shoots (Table 4) enables the use of Brachiaria brizantha cv. Marandu as bioremediation plant in Se-rich areas, to reduce the levels of the element in the local soil. Forage can also be used as feed component, as long as the Se level is controlled, as highlighted by Rogers et al. (1990), whereas plant material from Se-rich areas can be used as silage or hay, diluted in material from safe areas.

At the end of the experiment, soil Se was below the initial content. The reduction of Se in the soil was due to the export of the element by the plant and possibly by the immobilization of Se in the soil by clay adsorption or forms of complexing with organic matter and Fe oxides or hydroxides. The Se adsorption capacity of Oxisol varied (134 to $2,246 \mathrm{mg} \mathrm{kg}^{-1}$ ) and the clay content was most closely related to soil Se adsorption (Mouta et al., 2008). Despite the reduction in available Se levels in the soil, the treatments only had effects on the Argissolo Amarelo Distrófico abrúptico (Arenic Hapludult) (Table 5).

Argissolo Amarelo Distrófico abrúptico (Arenic Hapludult) treated with ammonium sulfate had the highest available Se content and in the Latossolo Vermelho Distroférrico (Rhodic Hapludox), S contents were highest in the treatments with ammonium sulfate and ferric sulfate (Table 5). The high soil content of available Se in this treatment was not enough to increase the plant Se contents or total exported Se in comparison with the control (Table 4).

The differences in the potential of Se uptake inhibition observed between $\mathrm{S}$ sources resulted from differences in Se or S solubility and consequently, in the availability of sulfate anions (Table 5). Calcium sulfate is a poorly water-soluble $\mathrm{S}$ source, which can raise the ionic strength of the soil solution, resulting in a continuous release of salt ions to the solution over long periods (Sousa et al., 2007). Thus, the remediation potential of calcium sulfate was lowest because of the low S-solubilization speed.

Table 5. Content of selenium and sulfur in the three studied soils after cultivation of Brachiaria brizantha cv. Marandu treated with sulfur sources

\begin{tabular}{|c|c|c|c|c|}
\hline Soil & Control & Ammonium sulfate & Calcium sulfate & Ferric sulfate \\
\hline & \multicolumn{4}{|c|}{ Selenium $\left(\mathrm{mg} \mathrm{kg}^{-1}\right)$} \\
\hline Argissolo Amarelo Distrófico abrúptico & $1.11 \mathrm{~b}$ & $2.79 \mathrm{a}$ & $1.58 \mathrm{~b}$ & $1.15 \mathrm{~b}$ \\
\hline Latossolo Vermelho Distroférrico & $0.14 \mathrm{a}$ & $0.20 \mathrm{a}$ & $0.24 \mathrm{a}$ & $0.27 \mathrm{a}$ \\
\hline \multirow[t]{2}{*}{ Nitossolo Vermelho Eutroférrico } & $1.21 \mathrm{a}$ & $1.06 \mathrm{a}$ & $0.98 \mathrm{a}$ & $1.25 \mathrm{a}$ \\
\hline & \multicolumn{4}{|c|}{ Sulfur (mg kg $\left.{ }^{-1}\right)$} \\
\hline Argissolo Amarelo Distrófico abrúptico & $10 \mathrm{~b}$ & $131 \mathrm{a}$ & $15 \mathrm{~b}$ & $121 \mathrm{a}$ \\
\hline Latossolo Vermelho Distroférrico & $18 \mathrm{~b}$ & $270 \mathrm{a}$ & $25 \mathrm{~b}$ & $276 \mathrm{a}$ \\
\hline Nitossolo Vermelho Eutroférrico & $23 \mathrm{~b}$ & $172 \mathrm{a}$ & $24 \mathrm{~b}$ & $214 \mathrm{a}$ \\
\hline
\end{tabular}

Means followed by the same lowercase letters in a row do not differ by the Tukey test $(\mathrm{p}<0.01)$. 


\section{CONCLUSIONS}

High levels of Se-uptake affect biomass production of Brachiaria brizantha cv. Marandu, regardless of the soil type.

Sulfur application in soluble sources such as ammonium sulfate and ferric sulfate reduces Se-uptake by Brachiaria grass.

The low solubility of calcium sulfate resulted in low effectiveness in reducing Se uptake by Brachiaria grass.

\section{REFERENCES}

Abreu LB, Carvalho GS, Curi N, Guilherme LRG, Marques JJGSM. Sorção de selênio em solos do bioma cerrado. R Bras Ci Solo. 2011;35:1995-2003.

Adriano DC. Selenium. In: Adriano DC, editor. Trace elements. Berlin: Springer-Verlag; 1986. p.390-416.

Allaway WH. Control of the environmental levels of selenium. In: Hemphill DD, editor. Trace substances in environmental health. II. Columbia: University of Missouri; 1968. p.181-206.

Association of Official Analytical Chemists - AOAC. Official methods of analysis. Washington, DC: 1980.

Cantarella H. Nitrogênio. In: Novais RF, Alvarez VVH, Barros NF, Fontes RFF, Cantarutti RB, Neves JCL, editores. Fertilidade do solo. Viçosa, MG: Sociedade Brasileira de Ciência do Solo; 2007. p.375-470.

Casteel SW, Blodgett, D.J. Selenium. Metals and minerals. In: Plumlee KH, editor. Clinical veterinary toxicology. Missouri: Mosby Incorporation St. Louis; 2004. p.214-7.

Combs Jr, GF, Combs SB. Selenium in the environment. In: Combs Jr GF, Combs SB, editors. The role of selenium in nutrition. Orlando: Academic Press; 1986. p.15-40.

Costa KAP, Rosa B, Oliveira IP, Custódio DP, Silva DC. Efeito da estacionalidade na produção de matéria seca e composição bromatológica da Brachiaria brizantha cv. Marandu. Ci Anim Bras. 2005;6:187-93

Dhillon KS, Dhillon SK. Distribution and management of seleniferous soils. Adv Agron. 2003;79:119-84.

Empresa Brasileira de Pesquisa Agropecuária - Embrapa. Serviço Nacional de Levantamento e Conservação de Solos. Manual de métodos de análise de solo. Rio de Janeiro: 1979.

Lewis LD. Nutrição clínica equina: Alimentação e cuidados. São Paulo: Rocca; 2000.
Malavolta E. Selênio. In: Malavolta E, editor. Elementos de nutrição mineral de plantas. São Paulo: Agronômica Ceres; 1980. p.211-2.

Malavolta E. Selênio. In: Malavolta E, editor. Manual de nutrição mineral de plantas. São Paulo: Agronômica Ceres; 2006. p.396-401.

Mouta ER, Melo WJ, Soares MR, Alleoni LRF, Casagrande JC. Adsorção de selênio em Latossolos. R Bras Ci Solo. 2008;32:1033-41.

National Research Council - NRC. Mineral tolerance of animals. 2nd.ed. Washington, DC: National Academy Press; 2005.

Oliveira KD, França TN, Nogueira VA, Peixoto PV. Enfermidades associadas à intoxicação por selênio em animais. Pesq Vet Bras. 2007;27:125-36.

Raij Bvan, Cantarella H, Quaggio JA, Furlani AMC. Análise química para avaliação da fertilidade dos solos tropicais. Campinas: Instituto Agronômico de Campinas; 2001.

Raij Bvan, Cantarella H, Quaggio JA, Furlani AMC. Forrageiras. In: Raij Bvan, Cantarella H, Quaggio JA, Furlani AMC, organizadores. Campinas: Instituto Agronômico de Campinas/ Fundação IAC; 1997. (Boletim técnico, 100).

Rios JJ, Blasco B, Rosales MA, Sanchez-Rodriguez E, Leyva R, Cervilla LM, Romero L, Ruiz JM. Response of nitrogen metabolism in lettuce plants subjected to different doses and forms of selenium. J Sci Food Agric. 2010;90:1914-9.

Rogers PAM, Arora SP, Fleming GA, Crinion RAP, Mclaughlin JG. Selenium toxicity in farm animals: treatment and prevention. Irish Vet J. 1990;43:151-3.

SAS Institute Inc. SAS OnlineDoc® 9.1.3. Cary, NC: 2004.

Sousa DMG, Miranda LN, Oliveira SA. Acidez do solo e sua correção. In: Novais RF, Alvarez VVH, Barros NF, Fontes RFF, Cantarutti RB, Neves JCL, editores. Fertilidade do solo. Viçosa, MG: Sociedade Brasileira de Ciência do Solo; 2007. p.205-74.

Sparks DL. Kinetics and mechanisms of chemical reactions at the soil mineral/water interface. In: Sparks DL, editor. Soil physical chemistry. 2nd.ed. New York: CRC Press; 1999. p.135-92.

Terry N, Zayed AM, Souza MP, Tarun AS. Selenium in higher plants. Ann Rev Plant Physiol Plant Molec Biol. 2000;51:401-32.

Yoon J, Cao X, Zhou Q, Ma LQ. Accumulation of Pb, Cu, and Zn in native plants growing on a contaminated Florida site. Sci Total Environ. 2006;368:456-64.

White PJ, Broadley MR, Bowen HC, Johnson SE. Selenium and its relationship with sulfur. In: Hawkesford, MJ, Kok LJD, editors. Sulfur in plants. The Netherlands: Springer; 2007. p.225-52.

Zhao C, Ren J, Xue C, Lin E. Study on the relationship between soil selenium uptake. Plant Soil. 2005;277:197-206. 